\title{
Indications of sandstone-type uranium mineralization from 3D seismic data: a case study of the Qiharigetu deposit, Erenhot Basin, China
}

\author{
Qubo $\mathrm{Wu}^{1} \cdot$ Yucheng Huang ${ }^{1}$
}

Received: 8 December 2020 / Accepted: 15 February 2021 / Published online: 2 March 2021

(c) The Author(s) 2021

\begin{abstract}
The primary exploration objective of Qiharigetu Sandstone-type Uranium (SU) deposit in the Erenhot Basin of China is to understand the stratigraphy, lithology and fault distribution of the target layer. Various geophysical techniques including gravity, magnetic, electromagnetic and 2D seismic have been proved not very effective due to its shallow depth of burial and small geophysical differences between layers. A specific 3D seismic survey of the Qiharigetu SU deposit has been carried out, and the inferred geological features of the uranium mineralization could provide important references for subsequent drilling programs. It is deduced that the target layer in the central part of the study area has a local "depression" through 3D seismic imaging and interpretation, which is conducive to river runoff and formation of sand body, as the sand body is a necessary precondition for mineralization. There are faults (5-50 m in throw) striking north-south for around $2 \mathrm{~km}$, and it is an important ore-controlling factor, which could provide channels for the rise of reducing agents (such as gas, $\mathrm{H}_{2} \mathrm{~S}$, and coalbed methane) at depth as they can promote the redox reaction for mineralization. The 3D seismic inversion is used to estimate the impedance, lithology, sand content and porosity of the target layer. With the help of drilling verification, it is found that the area with sand content over $75 \%$ and porosity over $10 \%$ is favorable for the SU deposit. Compared with other geophysical techniques, 3D seismic method is able to provide high-resolution images for unraveling SU mineralization and thereby reduce the drilling risk of the SU deposit.
\end{abstract}

Keywords 3D Seismic reflection $\cdot$ Interpretation $\cdot$ Inversion $\cdot$ Sandstone-type uranium deposit

\section{Introduction}

Sandstone-type uranium (SU) deposits are mainly developed in sandstones in Mesozoic and Cenozoic sedimentary basins (Kang et al. 2020). They have become one of the fastest growing, largest uranium resources in China (Zhang et al. 2010; Chen et al. 2011; Cai et al. 2015). In recent years, a number of uranium deposits have been discovered in the Erenhot Basin of China, one of which is the Qiharigetu SU deposit. The main exploration problem of the Qiharigetu SU deposit is to understand the stratigraphy, lithology and fault distribution of the target layer. Various geophysical techniques have been used to detect the above geological features to date, yet with no satisfactory results yielded. In terms of

Qubo Wu

wdyqthl@163.com

1 China National Nuclear Corp Beijing Research Institute of Uranium Geology, Chaoyang District, Beijing 100029, China previous work, gravity and magnetic methods were used to roughly sketch the geological tectonic units, but they were unable to detect the vertical characteristics of deep layers; electromagnetic methods couldn't deduce the stratigraphy and lithology of the target layer accurately (Zhao et al. 2010) because of the small electrical differences; the 2D seismic reflection was employed to infer the geological structure, lithology (Wu and Li 2015), faults, paleochannels (Wu et al. 2015) and has also obtained some good exploration results in exploring SU metallogenic environments (Wu et al. 2017), but the resolution is still limited in detecting small faults with a throw less than $20 \mathrm{~m}$ and thin-beds with thickness less than $20 \mathrm{~m}$, and the lateral variation of the geological features are difficult to track through 2D seismic interpretation. Hence, a high-resolution characterization of the Qiharigetu SU deposit has created a need for 3D seismic exploration.

As is well-known, 3D seismic method has been widely used in the exploration of petroleum (Torres-Verdin et al. 2000; Sharp and Samuel 2004; Nyamapfumba and McMechan 2012; Chen et al. 2016; Yang et al. 2018), coal 
(Zhou et al. 2007; Yuan et al. 2010; Han et al. 2015; Li et al. 2015) and other resources (Milkereit et al. 2000; Urosevic et al. 2012; White et al. 2012; Manzi et al. 2012). However, its full application and acceptance by the uranium geology industry started just recently: Applegate et al. (1982) led a pioneering seismic research of the Gas Hills uranium deposit; Gyorfi et al. (2007) conducted a high-resolution seismic survey by the McArthur River, which enabled a complex P2 high-precision detection of structural development and fracture distribution of uranium deposits; Hajnal et al. (2010) applied 2D and 3D seismic reflection surveys in exploring the SU deposits of the Athabasca Basin, Canada, pointing out that 3D seismic surveys can achieve a detailed delineation of the local structure of the mineralized region and can further enhance the efficiency of drilling production; Juhojuntti et al. (2012) performed a 3D seismic survey covering $6.5 \mathrm{~km}^{2}$ of the Millennium uranium field in Canada. The work obtained a good 3D characterization of the complex structure and unconformities in the study area and revealed the post-Athabasca fault zone located near the ore body. In the past decade or so, a large number of 2D seismic surveys of SU deposits have been carried out in several large basins in northern China, and the applications have shown that 2D seismic method can basically identify the stratigraphy, structure, large sets of sand bodies, etc. of target layers. The above 3D seismic exploration cases are all for unconformity-type uranium deposits, and there are many 2D seismic exploration cases for SU deposits. But the 3D seismic method for SU deposits has yet been applied before, there is no accumulated technical experience for it, and the seismic indicators of uranium formation have not been researched out.

This paper, based on the "Long Can" research project of China National Nuclear Corporation (CNNC), uses 3D seismic method to predict uranium mineralization in Qiharigetu with respect to the stratigraphic structure, fracture, sand body, porosity, etc., forming an effective set of seismic data acquisition and processing experiences, and finds the indirect seismic signatures of the SU deposit in this area, which provides valuable support for later drilling work.

\section{Geologic setting}

The test area, Qiharigetu depression, is located in the central part of the Erenhot Basin, covering an area of about 10 $\mathrm{km}^{2}$ (Fig. 1). The basement mainly consists of shallow and mediocre-level Paleozoic metamorphic rocks and Jurassic volcanic rocks (Liu et al. 2013, 2018). The sedimentary cap rock is comprised of Cretaceous, Palaeomorphic, Neogene and Quaternary deposits. The Cretaceous Arshan Group $\left(\mathrm{k}_{1} \mathrm{a}\right)$ and Tengger Group $\left(\mathrm{k}_{1} \mathrm{t}\right)$ are both oil-bearing layers, primarily containing sandstone and mudstone. The Saihan
Group $\left(\mathrm{k}_{1} \mathrm{~s}\right)$ is a coal-bearing layer, which is also the target zone in this area. The Erenhot Group $\left(\mathrm{k}_{2} \mathrm{e}\right)$ is also dominated by sandstone and mudstone, which are also the predominant lithology of the overlying Palaeogene and Neogene sediments with mudstone interbedded. The Quaternary section is mainly alluvial deposits. The area is covered by sediments with no faults outcropped.

The mine in this area is a typical interbedded oxidized zone-type uranium deposit (Liu et al. 2013; Nie et al. 2015). The mineralization process is briefly described as follows: Surface water carrying oxygen and $\mathrm{U}^{6+}$ flows through the sand body of the target layer and initiates the redox reactions with the reducing agent in the sand body, resulting in the deposition of $\mathrm{U}^{4+}$ and precipitation of mineralization.

The velocities and densities of the basement and sedimentary cover rocks are shown in Table 1. Overall, there is a P-wave impedance difference between the layer groups and between the various lithologies, which is a prerequisite for seismic application.

The precipitation of the SU deposit is controlled by several factors such as sand bodies, structural depressions, reducing substances, fracturing, etc., as sand bodies determine the accommodation space of the ore body, whereas depressions are good for the flow of oxygenated uraniumbearing groundwater, and fracturing enables the oxidative modification of sand bodies by controlling the rise of reducing gases. Current research shows that the SU deposit presents no significant seismic response, but 3D seismic method makes it possible to detect these controlling factors and indirectly predict favorable areas for uranium mineralization.

\section{Data acquisition and processing}

\section{The acquisition parameters of the 3D seismic survey are as follows:}

- Spread patch for acquisition: 16 Receiving lines $\times 4$ Sources $\times 128$ Receivers.

- Geometry for one survey line: 635 m-5 m-10 m-5 m-635 m.

- Bin size: $5 \mathrm{~m} \times 10 \mathrm{~m}$.

- Nominal stack folds: 128.

- Interval of geophones: $10 \mathrm{~m}$.

- Interval of sources: $20 \mathrm{~m}$.

- Receiver line spacing: $80 \mathrm{~m}$.

- Source line spacing: $40 \mathrm{~m}$.

- Source: One vibroseis, 65,000 lbs.

- Sweep frequencies: 3-120 Hz.

- Natural frequency of Geophone: $5 \mathrm{~Hz}$.

- Acquisition system: 428XL. 


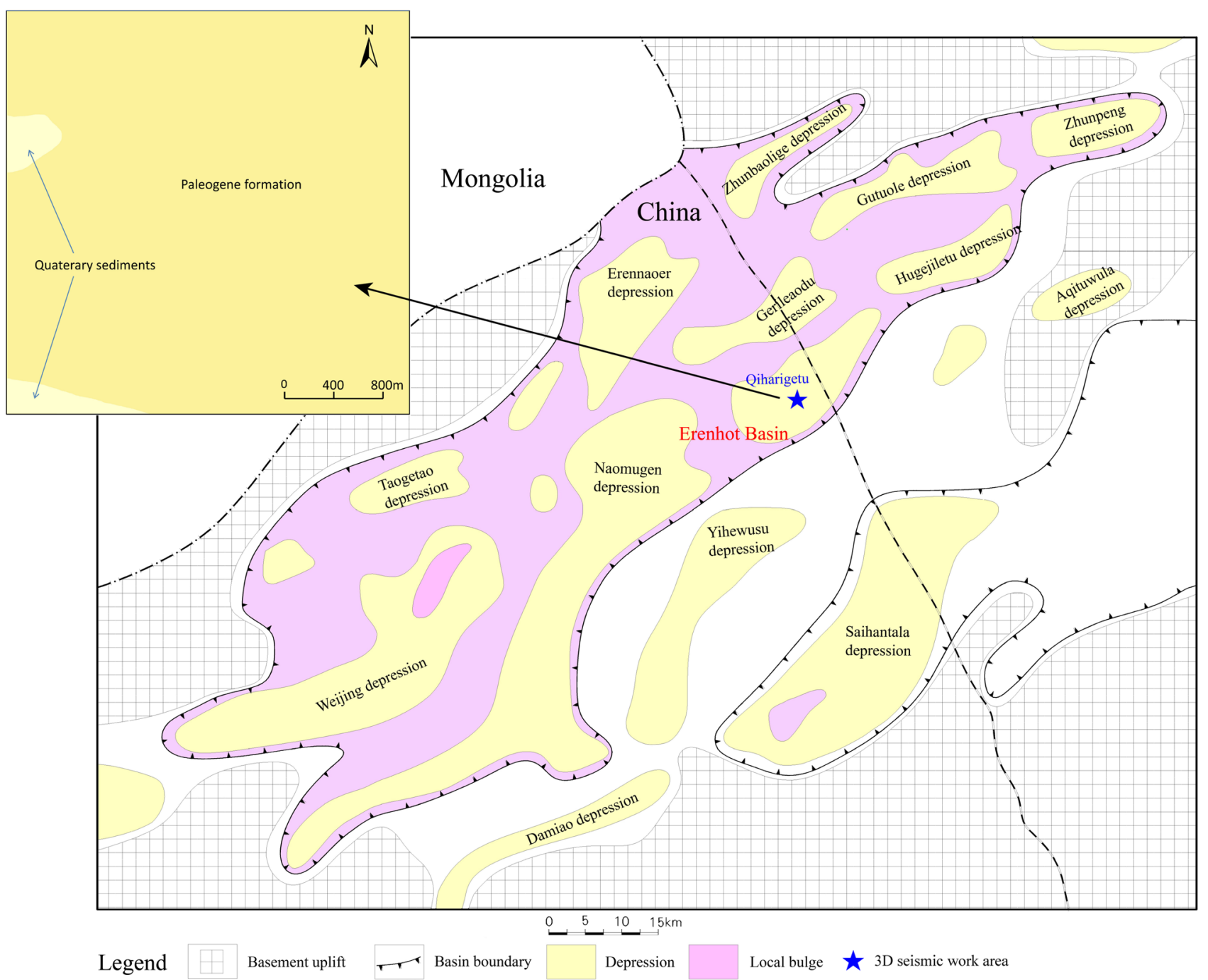

Fig. 1 The structural outline map of Erenhot Basin

The processing flow is shown in Fig. 2

\section{Results and discussion}

\section{Worthy of attention in seismic data acquisition of SU deposits.}

It is worth noting in seismic data acquisition of the SU deposit that the use of small bins $(5-10 \mathrm{~m})$ increases the spatial sampling rate of shallow target layers so as to improve signal-to-noise ratio. In SU seismic exploration, fold number of 60 can balance the exploration effects and cost; the azimuthal angle is maximized to above 0.9 in order to guarantee wide orientation imaging for fault and sand body identification. The source excitation using a small number of vibrations and a broad sweeping band, preferably down to $1 \times 1$ and 3 to $120 \mathrm{~Hz}$, respectively, is to broaden the bandwidth of the excitation signal and thus improve the resolution of the data, which is beneficial to the identification of thin beds that may be mineralized. We can see from Fig. 3 that the spectral bandwidth of the target layer of the raw data collected at this time is wider than the one in the past, it is partly why we can improve the detection precision sharply of the layers, faults, sand bodies related to $U$ mineralization (Fig. 4).

\section{Worthy of attention in seismic data processing for SU deposits}

The data processing results shown in Fig. 5 have good accuracy, we could easily identify the layers and deduce the faults from processed data. There are a few points worth noting for data processing of SU deposits. 
Table 1 Physical properties of stratum in work area

\begin{tabular}{|c|c|c|c|}
\hline Stratum symbol & Lithology & Density $\left(\mathrm{g} / \mathrm{cm}^{3}\right)$ & $\begin{array}{l}\text { Acoustic inter- } \\
\text { val transit time } \\
\text { (us/m) }\end{array}$ \\
\hline Q & Gravel, clay & Avg 1.45 & $800-1250$ \\
\hline $\mathrm{N}$ & $\begin{array}{l}\text { Pebbled sand- } \\
\text { stone }\end{array}$ & Avg 1.78 & $650-900$ \\
\hline E & $\begin{array}{l}\text { Mudstone, } \\
\text { siltstone }\end{array}$ & Avg 1.67 & $400-900$ \\
\hline \multirow[t]{5}{*}{$\mathrm{K}_{2} \mathrm{e}$} & Mudstone & $1.8-2.0$ & $560-720$ \\
\hline & Siltstone & $1.9-2.1$ & $420-480$ \\
\hline & Fine sandstone & $1.9-2.2$ & $380-480$ \\
\hline & Sandstone & $2.0-2.2$ & $380-480$ \\
\hline & $\begin{array}{l}\text { Sandy conglom- } \\
\text { erate }\end{array}$ & $2.1-2.3$ & $270-340$ \\
\hline \multirow[t]{4}{*}{$\mathrm{K}_{1} \mathrm{~s}$} & Mudstone & $1.8-2.0$ & $600-660$ \\
\hline & Siltstone & $1.9-2.1$ & $570-620$ \\
\hline & Sandstone & $1.9-2.1$ & $230-390$ \\
\hline & $\begin{array}{l}\text { Sandy conglom- } \\
\text { erate }\end{array}$ & $1.9-2.3$ & $240-350$ \\
\hline $\mathrm{J}$ & $\begin{array}{l}\text { Limestone, } \\
\text { volcanic }\end{array}$ & Avg 2.55 & $310-400$ \\
\hline
\end{tabular}

\begin{tabular}{|c|l|}
\hline Order & \multicolumn{1}{|c|}{ Process } \\
\hline 1 & Editing and geometry assignment \\
\hline 2 & Refraction statics \\
\hline 3 & Adaptive surface wave attenuation \\
\hline 4 & Radon(tau-p) filtering \\
\hline 5 & Amplitude compensation \\
\hline 6 & Deconvolution \\
\hline 7 & Velocity analysis and muting test(1) \\
\hline 8 & Residual statics(1) \\
\hline 9 & Velocity analysis and muting test(2) \\
\hline 10 & Residual statics(2) \\
\hline 11 & Velocity analysis and muting test(3) \\
\hline 12 & Residual statics(3) \\
\hline 13 & Pre-stack time migration \\
\hline 14 & Common-midpoint(CDP) stacking \\
\hline & Frequency-offset(F-X) deconvolution \\
\hline
\end{tabular}

Fig. 2 Processing workflow for seismic data of sandstone-type uranium deposit.

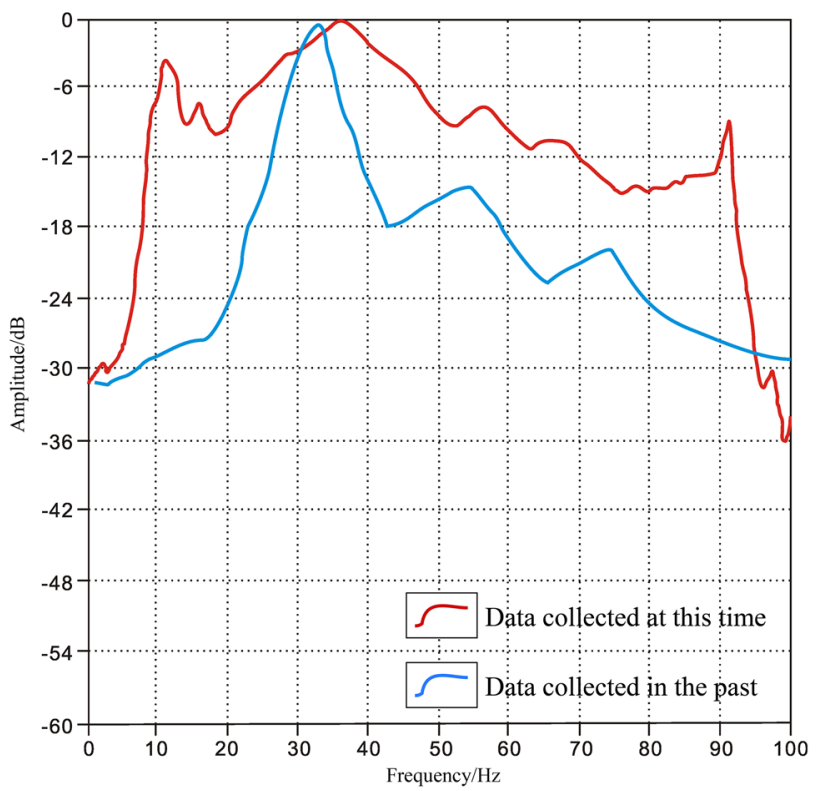

Fig. 3 Spectral comparison of raw data collected separately at this time and in the past

(1) A small top mute $(<10 \mathrm{~ms})$ should be used for the near offset for the shallow $(<500 \mathrm{~m})$ target layer of the SU deposit in the area. The Radom polynomial fitting is appropriate to denoise the shallow seismic.

(2) The tiny differences between the target sand body and its surrounding rock in terms of their petrophysical properties result in weak seismic reflections, so the recovery of this weak information should be enhanced in data processing. It turns out to be effective using spherical spreading compensation combined with the surface consistent amplitude compensation in this area.

(3) The SU deposits are often found in sand bodies with interbedded structures such as "mud-sand-mud" and "coal-sand-mud" pattern (Pan et al. 2015), and the thickness of the target layer varies from 10 to several tens of meters, requiring high resolution of the processing data, so the spectrum equalization technique should be used necessarily to improve the resolution of prestack seismic gathers.

\section{Data interpretation and inversion results}

\section{Stratigraphic morphology and structural characteristics of typical profile}

The synthetic seismogram calculated by borehole data could bridge seismic events and geological horizons, the seismic events should be correlated to geological horizons by using synthetic seismogram prior to data interpretation. The target layer Saihan Group is divided into four sub-layers, S1, S2, 


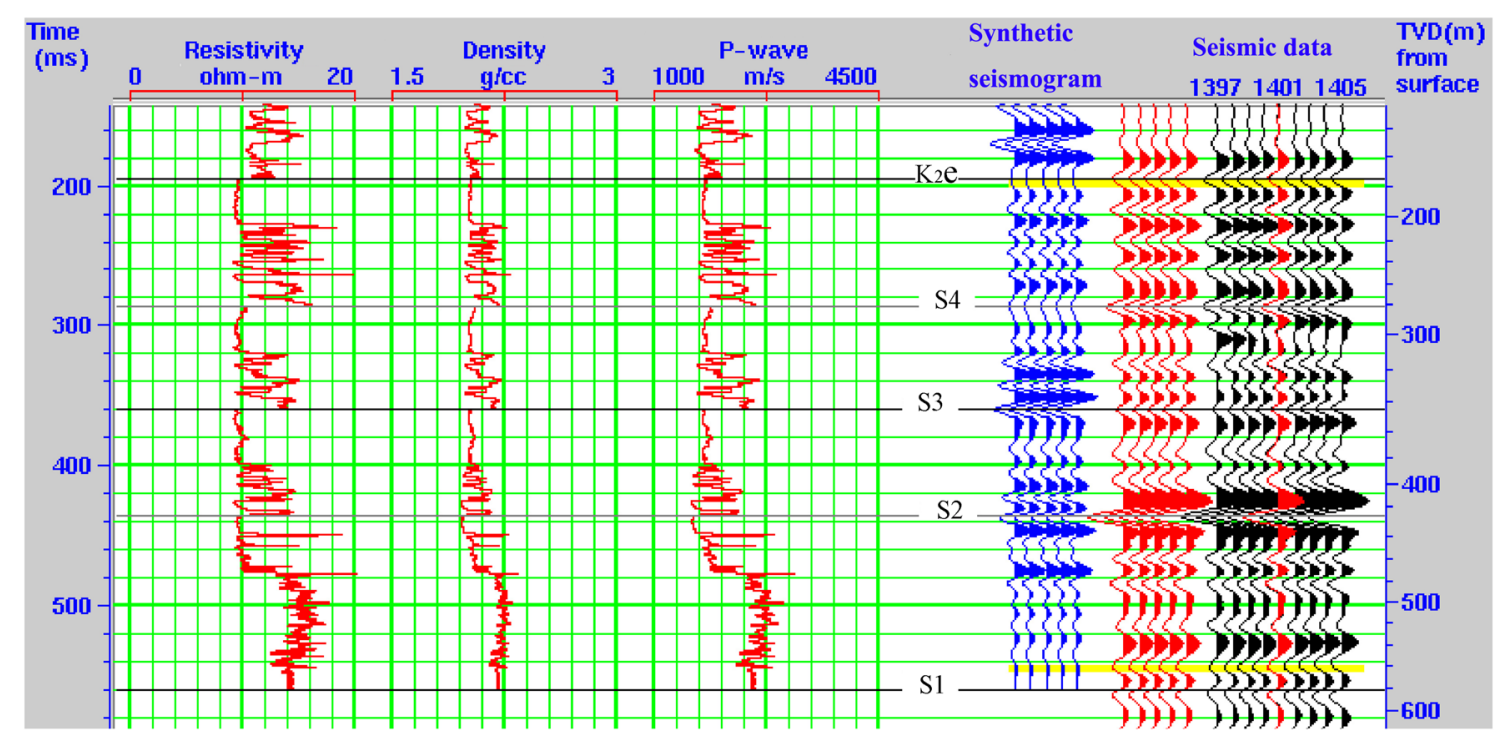

Fig. 4 Synthetic seismic record of a typical borehole

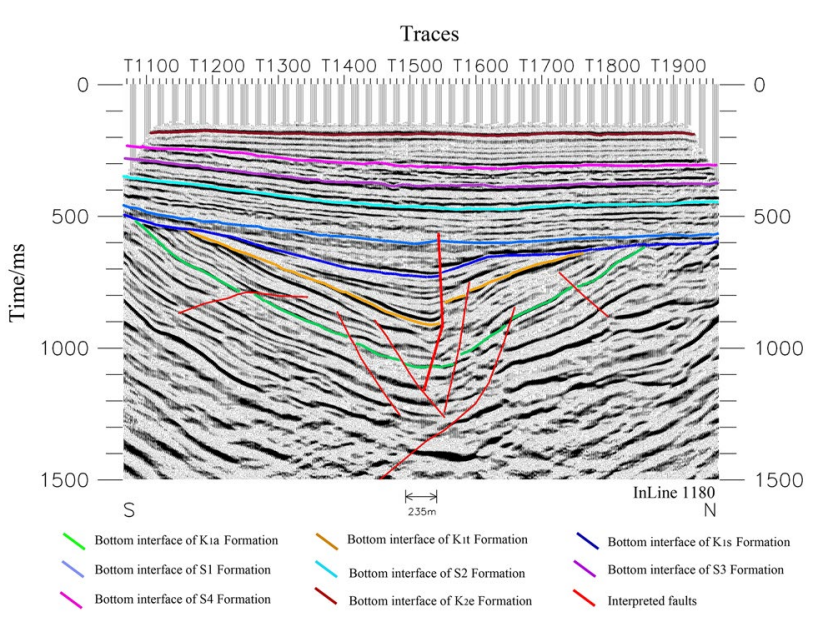

Fig. 5 Seismic interpretation results of typical line (InLine 1180)

S3, and S4 formations. All these sub-layers are substantially flat formations, which are conducive to the stable deposition of SU ore bodies and favorable to uranium enrichment. On the other hand, faults developed in the underlying Tengger Group and the Arshan Group and cut through the bottom of the Saihan Group, which is critical to uranium mineralization. These faults provide rising channels for reducing substances in depth such as gas, $\mathrm{H}_{2} \mathrm{~S}$ and coalbed methane, which promote the redox of $\mathrm{U}^{6+}$ to form $\mathrm{U}^{4+} \mathrm{SU}$ deposit.

\section{Structural characteristics of the target layer}

The bottom of the Saihan group reflects the undulating topography (Fig. 6), and it is clear to see that the red and yellow areas in the central part represent a local depression, which is conducive to the pooling of water and the formation of potentially mineralized sand bodies, and there are four faults, F1, F2. F4 and F2-6, where F4 and F2-6 are small in size (up to a minimum throw of about $5 \mathrm{~m}$ ), while the F1 and F2 fracture present large scales (up to about $50 \mathrm{~m}$ ). As is mentioned above, these faults turn to be important conduits for the escape of deep reducing gas upward from the underlying hydrocarbon-bearing Tengger and Arshan Formations. The ascent of the reducing gas into the Saihan Group Formation can enhance the reductive capacity, which results in redox interactions with oxygenated uranium-bearing groundwater to form uranium mineralization.

\section{Sandstone distribution in the target layer}

The impedance of the target layer was obtained by the model-based inversion (Fig. 9c), the statistical wavelet calculated by seismic data near the well FZK497-255 was used in the inversion (Fig. 8a) because it has logging data with good quality, and the inversion error and correlation is about 760 and 0.945, respectively, in the inversion (Fig. 9b). The threshold for distinguishing sandstone from mudstone was obtained via petrophysical analysis from the well data (Fig. 7). Figure 7 shows the inverted 3D sand bodies of the Saihan formation (the target layer), and Fig. 8 shows the predicted lithology of an arbitrary line across three wells. The high and low values of the inserted P-wave curves indicate sandstone and mudstone, respectively.

The result of lithology prediction shows four big sets of sand bodies, namely S1, S2, S3 and S4 bodies, each of which has several small sets of sand bodies. Some parts of

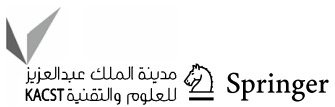




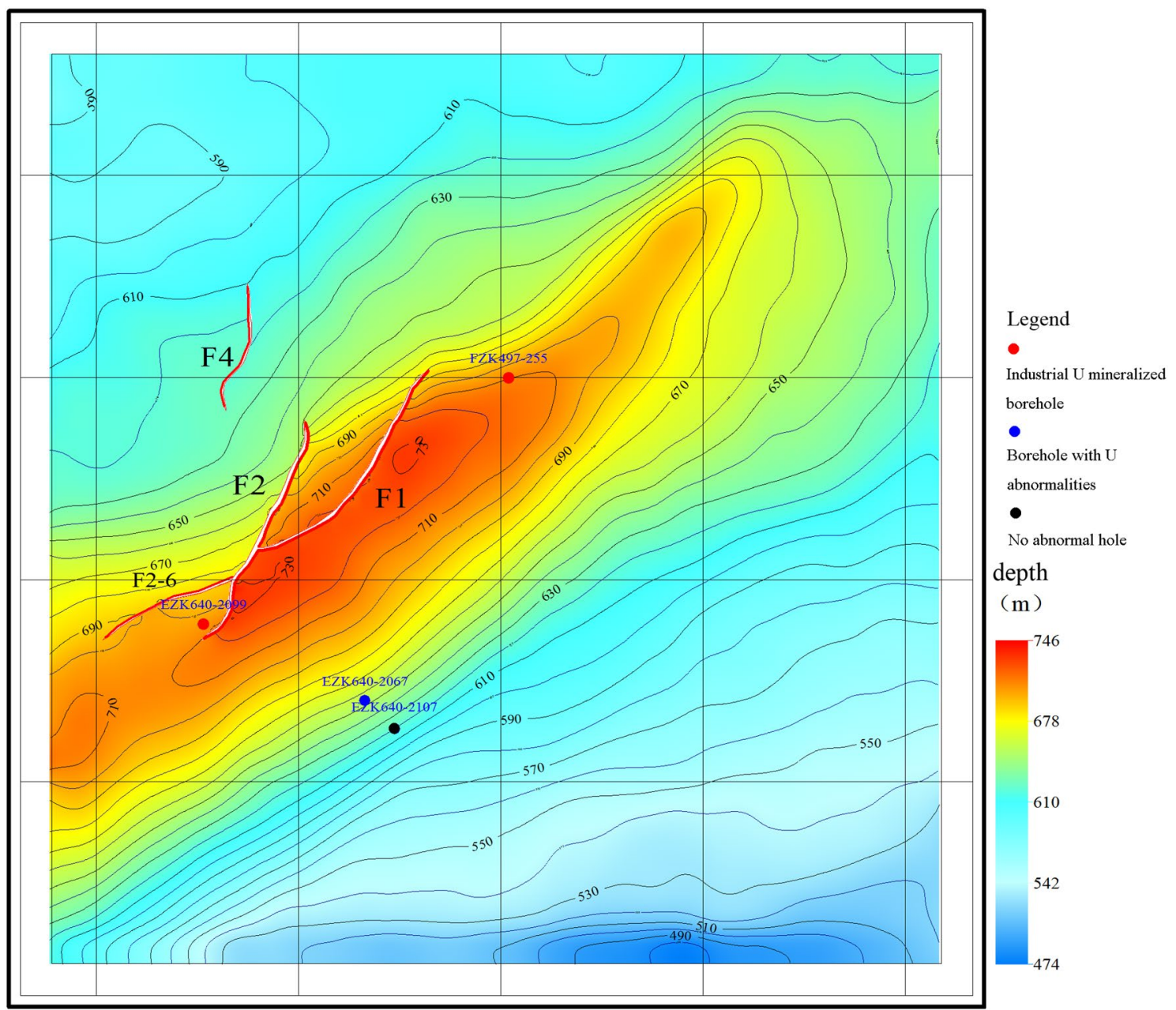

Fig. 6 The structural map of bottom interface of Saihan formation $\left(\mathrm{K}_{1} \mathrm{~s}\right)$ in depth domain

the sand bodies present high-resolution results of inversion. For example, the lithological section shows that sand bodies of $5 \mathrm{~m}$ and $6 \mathrm{~m}$ can be recognized around the middle and lower part of the well FZK497-255, whereas thin bed of mudstone of $5 \mathrm{~m}$ can be recognized around the upper part of the well EZK640-2099 (red arrows).

Since the S1, S2, S3 and S4 sections are formed in a "mud-sand-mud" structure, there is a possibility of mineralization in terms of stratigraphy and lithology. However, based on the above structural analysis, only the bottom of $\mathrm{S} 1$ formation is cut through by faults, rendering reducing gas at depth spreads into the S1 sand body, while they cannot diffuse upward into the S2 sand body because of the obstruction by the upper mudstone cap. Therefore, among these four sand bodies, only the S1 section is enriched in reducing substances, which is favorable for uranium mineralization.

\section{S1 Sand body and its relationship to uranium mineralization}

(1) Sand content of the S1 Formation.

The sand content for the $\mathrm{S} 1$ formation can be calculated from the 3D lithologic data (Fig. 10), It can be seen that the area of high sand content (red and yellow parts) is well correlated with the uranium-mineralized holes (FZK497-255, EZK640-2099), whereas the low and mediocre content zones (green-blue part) corresponds well with the low-level U hole (EZK640-2067) and non-abnormal hole (EZK640-2107). It might be that high sand-bearing formation provides sufficient space for SU mineralization. Therefore, the relatively high sand-bearing area (above 0.75 ) is conducive to $\mathrm{SU}$ mineralization.

(2) S1 sand body porosity distribution. 

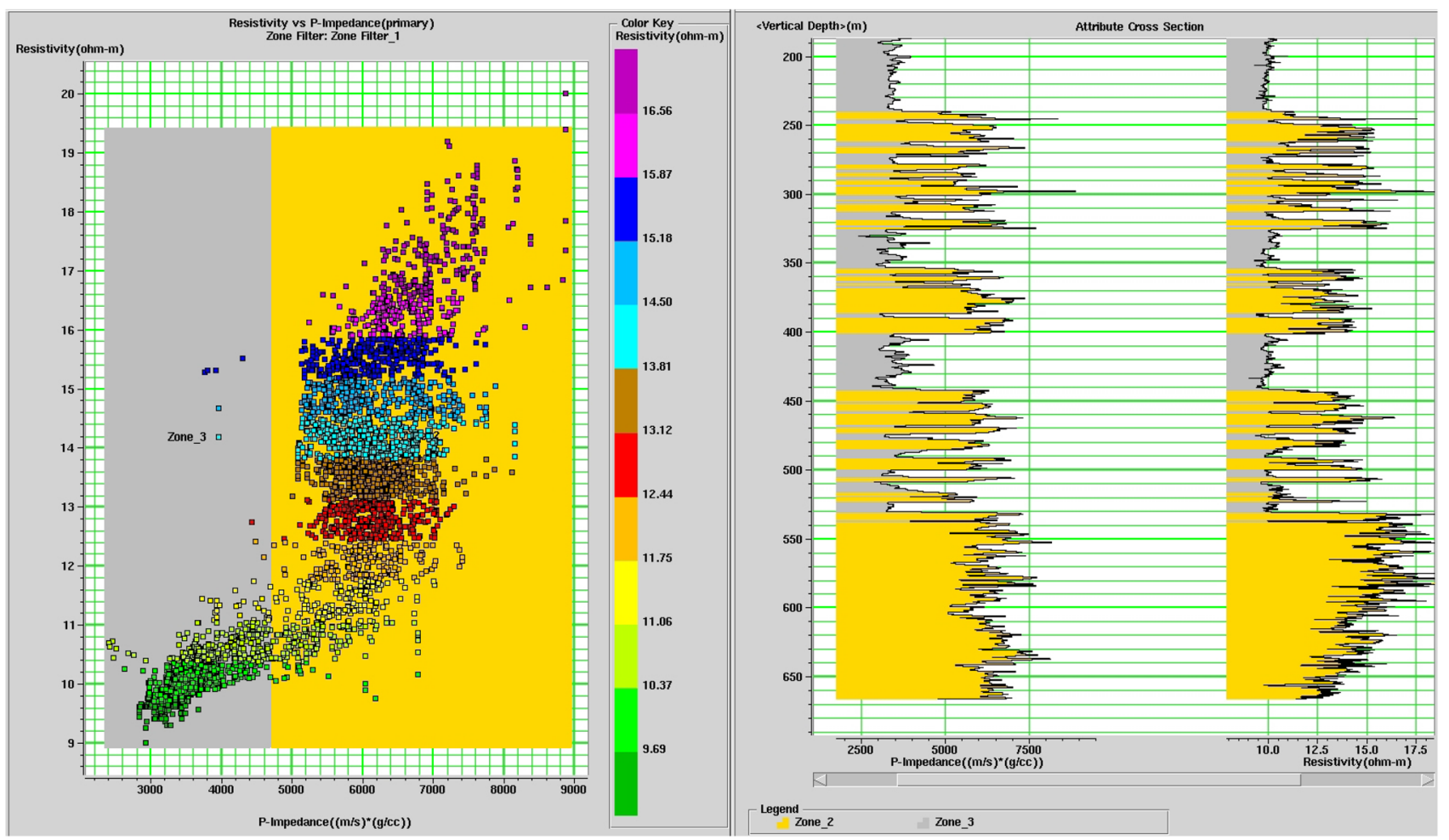

Fig. 7 Threshold of sandstone and mudstone was obtained by analysis of rock physics intersection

It is considered that $\mathrm{SU}$ mineralization is related to the porosity of the sand body. Due to the lack of well and rock physics data, the porosity of the $\mathrm{S} 1$ sand body can only be calculated by empirical conversion relationship between porosity and wave impedance (Eq. 1) from petroleum seismic experience in the work area.

$$
\text { por }=\frac{1000000 /\left(\frac{\mathrm{imp}}{0.33}\right)^{0.8}-\mathrm{AC}_{s}}{\mathrm{AC}_{f}-\mathrm{AC}_{s}}
$$

where the sonic time difference of the rock solid matrix $\mathrm{AC}_{s} \approx 180 \mu \mathrm{s} / \mathrm{m}$, and the sonic time difference of the pore fluid $\mathrm{AC}_{f} \approx 620 \mu \mathrm{s} / \mathrm{m}$. imp is the wave impedance and por is the porosity.

Figure 10 shows the average porosity distribution of the S1 sand body, the relative lateral variation is of critical significance. The industrial holes FZK497-255 and EZK640299 are located in the area of high porosity, and the mineralized holes EZK640-2067 and non-ore holes EZK640-2017 are located in the mediocre and low-porosity zones.

It is speculated that the greater the porosity of the sand body, the more favorable it is for groundwater flow and gas spreading. Therefore, it can be inferred that the reducing gas in the underlying Tengger and Arshan Groups will spread over the porous zone after rising along the faults to the S1 sand body. The hydrocarbon enhances the reducing capacity of the sand body in this north-eastward zone (denoted by the black dashed box), which is conducive to the redox reaction with uranium-bearing oxygen water and the formation of ore precipitation. Therefore, it is important to figure out the porosity distribution of the target layer for the analysis of uranium mineralization (Fig. 11).

\section{Comprehensive analysis}

The SU deposit is formed in a sand body with little petrophysical difference from the surrounding rocks, which leads to no direct seismic response to the SU deposit. However, the 3D reflection seismic method can be applied in identifying the favorable uranium mineralized environment, and thus in reducing the drilling risk.

(1) To be specific, the SU deposits in the study area are present in S1 formation for the following possible reasons: (1) The central depression is conducive to river runoff and the sand body is a necessary prerequisite as a large amount of sands provides sufficient space for mineralization. (2) The porous sand body is conducive to the flow of uranium-bearing oxygen groundwater and the spread of reducing gas. (3) The presence of

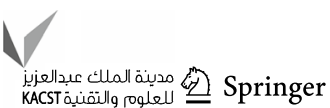




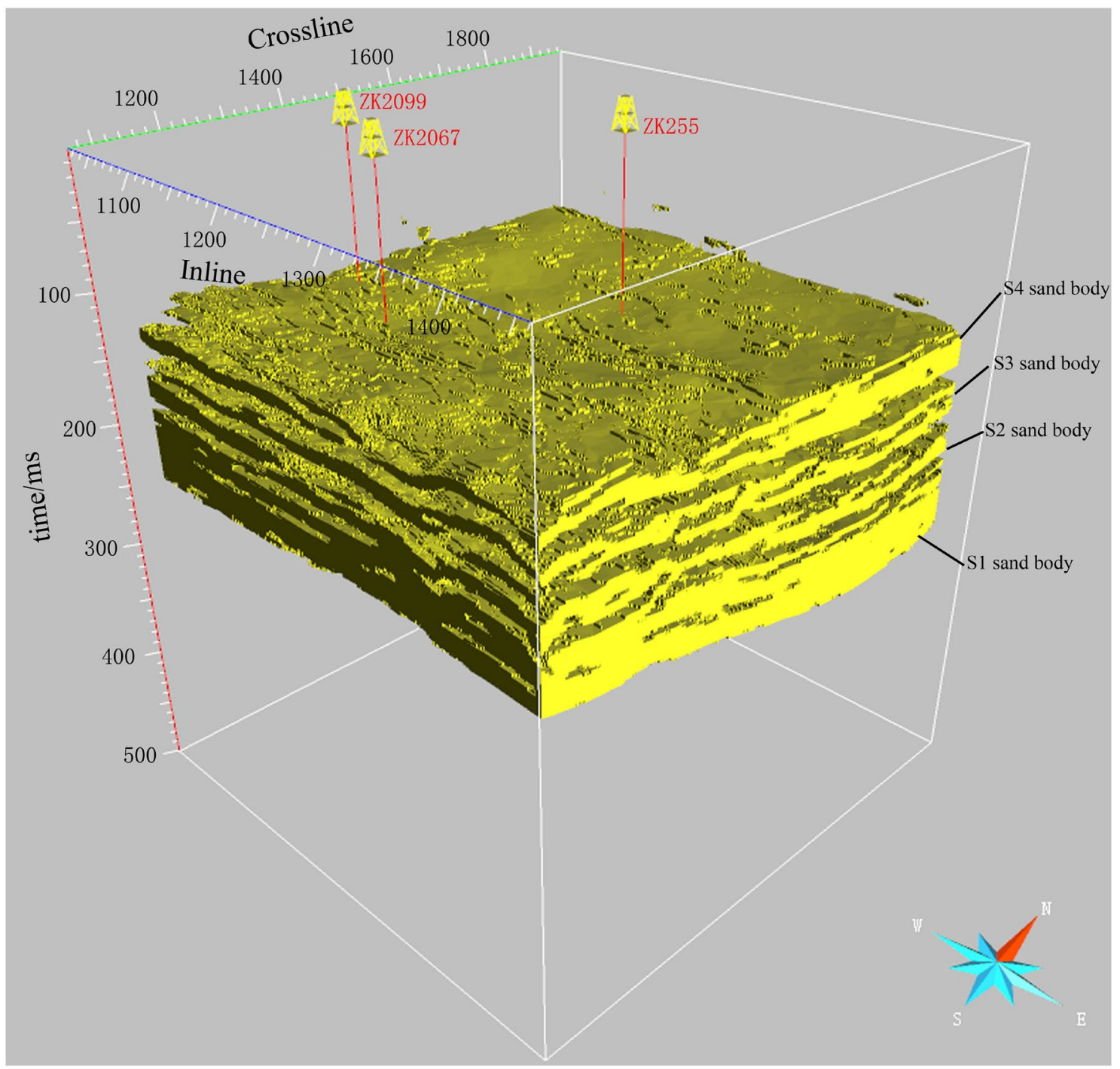

Fig. 8 3D sand bodies map of the upper section of Saihan Formation (including S1, S2, S3 and S4 sand bodies)

mudstone covering and underneath the S1 sand body builds up a trap helping to keep the fluids and reducing gas from running off. (4) That the faults cutting through the bottom of the Saihan Group opens up channels for the rising and diffusion of the hydrocarbons (e.g., oil and methane) at depth, enhancing the reducing capacity of the S1 sand body and thereby forming the uranium deposit through redox reactions.

(2) The frequency band of the current record in our work is $10-90 \mathrm{~Hz}$, which is wider than previous record (20$70 \mathrm{~Hz}$ ), and the main frequency of the target layer in our processed profile is about $35 \mathrm{~Hz}$. That may be why some thin-bed sands can't be identified in the seismic inversion.

(3) 3D seismic survey techniques are capable of identifying faults with several-meters separation, interpreting sandstone with several-meters thickness from this study.
Compared with the previous geophysical exploration results in the study area, the accuracy of this 3D seismic survey was improved greatly, and above geological discoveries can offer the effective indicators for later drilling plan in the work area.

(4) The study works of seismic petrophysical properties of SU deposits and seismic attribute characteristics of uranium-bearing reservoirs should be enhanced in the future in order to find direct seismic response for SU deposits.

\section{Conclusions}

(1) We consider it a success by following the acquisition specifications: a small bin size, a mediocre stack folds and wide-azimuth. Reducing the number of vibrators 

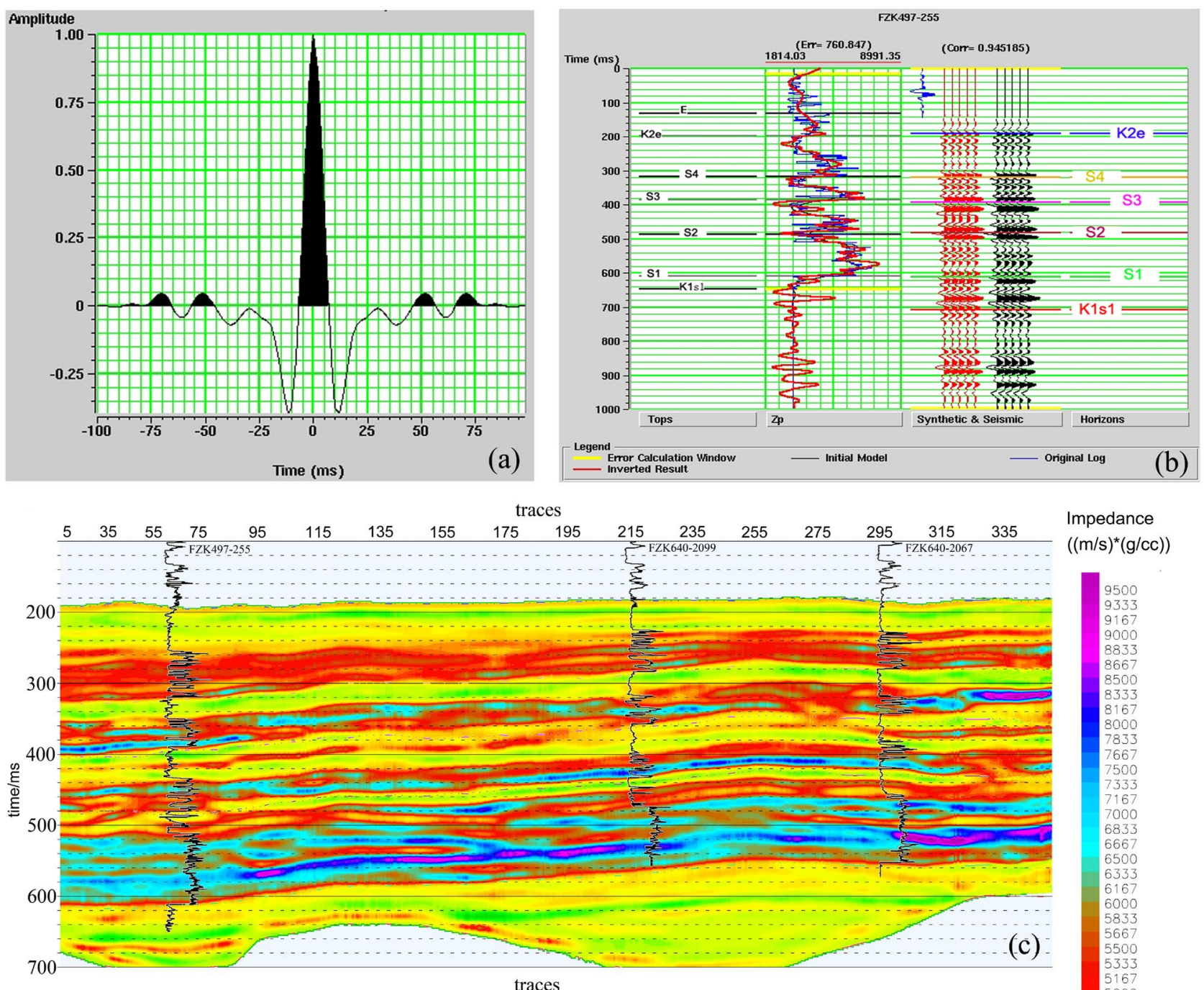

Impedance

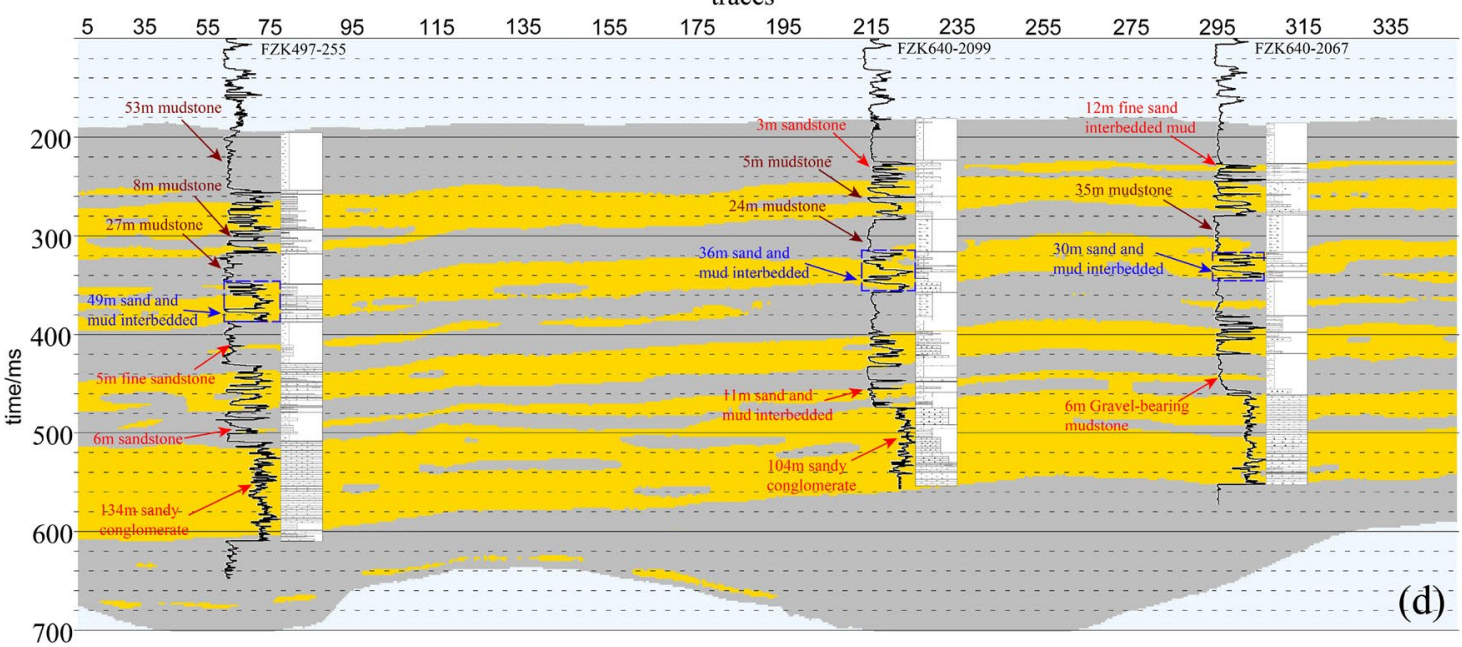

$\left((\mathrm{m} / \mathrm{s})^{*}(\mathrm{~g} / \mathrm{cc})\right)$

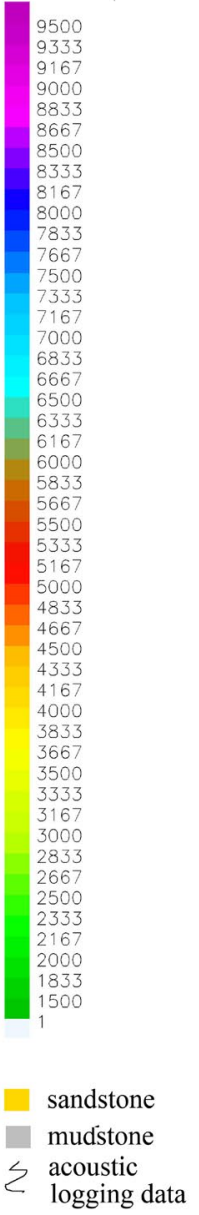

Fig. 9 The statistical wavelet (a) used in the inversion, error and correlation for typical borehole when seismic inverting (b), impedance results of the target layer (c) inverted by the model-based inversion method, comparison of lithological inversion results of arbitrary lines with borehole data $(\mathbf{d})$ 


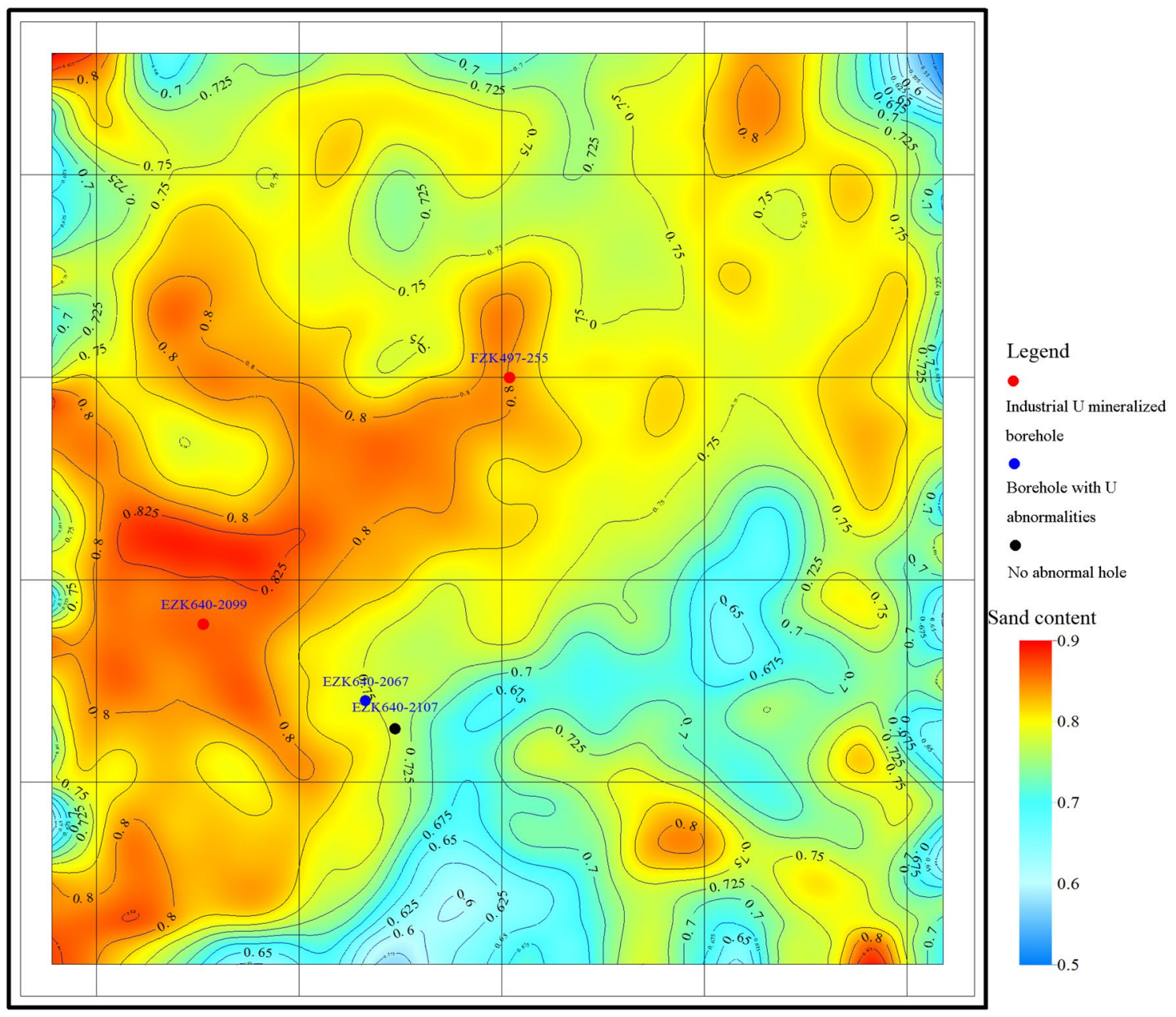

Fig. 10 The map of sand content in S1 formation

and vibrations as well as improving the bandwidth of excitation signal can broaden the frequency band of raw data. As for data processing of the SU deposit, accurate noise removal and NMO muting are critical for shallow seismic imaging. Meanwhile, it is necessary to adapt the effective amplitude compensation in order to enhance the weak seismic signal of sands within the target layer properly.

(2) 3D seismic data can provide interpretable geologic information for drilling of the study area. In spite that no obvious seismic response for the SU deposit has been found in this study, the metallogenic process of SU is controlled by local depressions, sand bodies, faults, reducing agents, etc. and the geologic environ- ment can be inferred precisely by 3D seismic application. Some important indicators for Qiharigetu SU deposits were found, such as local depression, faults cutting through the bottom of the target layer, "mudsand-mud" structure, high sand content (above 0.75) and high porosity zone (roughly greater than $10 \%$ ).

(3) The 3D seismic techniques have the best exploration precision in all geophysical methods for surveying SU deposit's environment. Hence, we expect developments and breakthroughs in exploration of SU deposits with further applications of 3D seismic technology. 


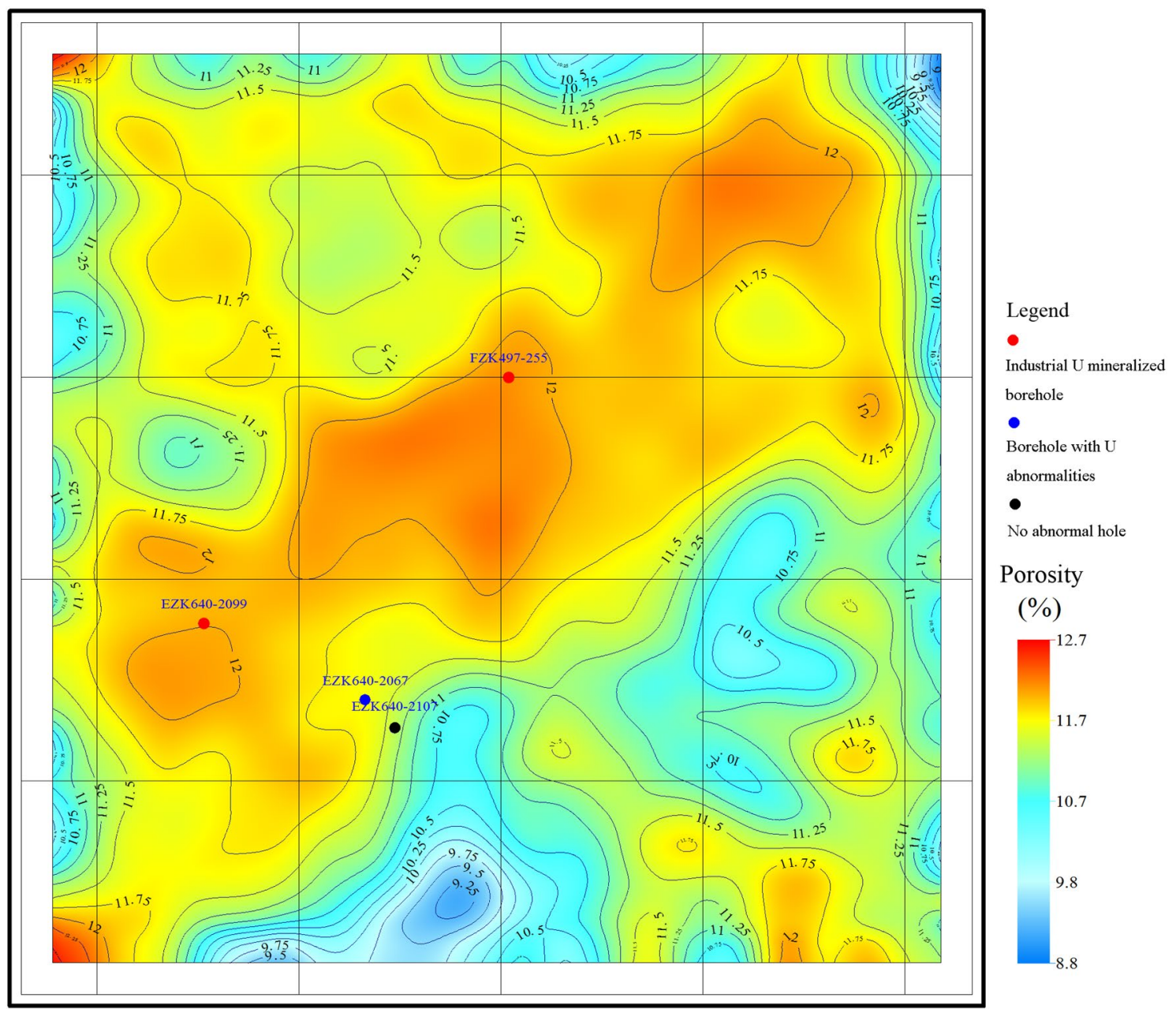

Fig. 11 The map of average porosity in $\mathrm{S} 1$ formation

Funding "Long Can" Scientific Research Project (Phase II) of China National Nuclear Corporation (Grant No. 2018-111).

Open Access This article is licensed under a Creative Commons Attribution 4.0 International License, which permits use, sharing, adaptation, distribution and reproduction in any medium or format, as long as you give appropriate credit to the original author(s) and the source, provide a link to the Creative Commons licence, and indicate if changes were made. The images or other third party material in this article are included in the article's Creative Commons licence, unless indicated otherwise in a credit line to the material. If material is not included in the article's Creative Commons licence and your intended use is not permitted by statutory regulation or exceeds the permitted use, you will need to obtain permission directly from the copyright holder. To view a copy of this licence, visit http://creativecommons.org/licenses/by/4.0/.

\section{References}

Applegate JK, Emilia DA, Neitzel EB (1982) High-resolution seismic study in the Gas Hills uranium district, Wyoming. Geophysics 47:1355-1374.
Cai YQ, Zhang JD, Li ZY et al (2015) Outline of uranium resources characteristics and metallogenetic regularity in China. Acta Geol Sin 89:1051-1069. https://doi.org/10.3969/j. issn.0001-5717.2015.06.005

Chen ZQ, Yang HF, Wang JB et al. (2016) Application of 3D highprecision seismic technology to shale gas exploration: a case study of the large Jiaoshiba shale gas field in the Sichuan Basin. Natural Gas Industry 36:9-20.https://doi.org/10.3787/j. issn.1000-0976.2016.02.002.

Chen ZY, Chen DS, Gu KH (2011) Study and evaluation of sandstonetype uranium deposits in China Volume III uranium deposits: Beijing Research Institute of Uranium Geology.

Gyorfi I, Hajnal Z, White DJ et al (2007) High-resolution seismic survey from the McArthur River region: contributions to mapping of the complex P2 uranium ore zone. Athabasca Basin, Saskatchewan. Geol Surv Canada 588:397-412

Hajnal Z, White DJ, Takacs E (2010) Application of modern 2-D and 3-D seismic-reflection techniques for uranium exploration in the Athabasca Basin: NRC Research Press Can. J Earth Sci 47:761-782

Han BW, Liu XB, Li Q, et al (2015) Coalfield Subsided Column and Gob Area Identification through 3D Seismic interpretation. Coal Geol China 27:67-70. https://doi.org/10.3969/j. issn.1674-1803.2015.09.16. 
Juhojuntti N, Wood G, Juhlin C (2012) 3D seismic survey at the Millennium uranium deposit, Saskatchewan, Canada: Mapping depth to basement and imaging post-Athabasca structure near the orebody. Geophysics 77:245-258

Kang H, Chen Y, Li D et al (2020) Deep-penetrating geochemistry for concealed sandstone-type uranium deposits: A case study of Hadatu uranium deposit in the Erenhot Basin, North China. J Geochem Explor 106464. https://doi.org/10.1016/j.gexplo.2020.10646 4

Li Q, Peng S, Zou G (2015) High resolution processing of 3D seismic data for thin coal seam in Guqiao coal mine. J Appl Geophys 115:32-39. https://doi.org/10.1016/j.jappgeo.2015.02.014

Liu WS, Kang SH, Jia LC et al (2013) Characteristics of Paleo-valley Sandstone-type Uranium Mineralization in the Middle of Erenhot Basin: Uranium. Geology 29:328-336. https://doi.org/10.3969/j. issn.1000-0658.2013.06.002

Liu WS, Zhao XQ, Kang SH et al (2018) Inversion structure and its relationship with Sandstone type Uranium metallization in Erenhot basin: uranium. Geology 34:81-89. https://doi.org/10.3969/j. issn.1000-0658.2018.02.003

Manzi MSD, Gibson MAS, Hein KAA, King N, Durrheim RJ (2012) Application of 3D seismic techniques to evaluate ore resources in the West Wits Line goldfield and portions of the West Rand goldfield, South Africa. Geophysics 77:163-171. https://doi. org/10.1190/geo2012-0133.1

Milkereit B, Berrer EK, King AR et al (2000) Development of 3-D seismic exploration technology for deep nickel-copper deposits - a case history from the Sudbury basin, Canada. Geophysics 65:1890-1899. https://doi.org/10.1190/1.1444873

Nie FJ, Li MG, Yan ZB et al. (2015) Segmentation of the target layer Saihan Formation and sandstone-type uranium mineralization in Erenhot Basin. Geol Bull China 34:1952-1963. https://doi. org/10.3969/j.issn.1671-2552.2015.10.020

Nyamapfumba M, McMechan GA (2012) Gas hydrate and free gas petroleum system in 3D seismic data, offshore Angola. Geophysics 77:55-63. https://doi.org/10.1190/geo2012-0048.1

Pan CY, Liu HX, Ding B et al. (2015) Skeleton sand body depositional characteristics of the lower member of Xishanyao Formation and their relationship to sandstone type uranium mineralization in the southern margin of Yili basin. World Nuclear Geosci 32:208216.https://doi.org/10.3969/j.issn.1672-0636.2015.04.004.

Sharp A, Samuel A (2004) An example study using conventional 3D seismic data to delineate shallow gas drilling hazards from the West Delta Deep Marine Concession, offshore Nile Delta. Egypt Petrol Geosci 10:121-129. https://doi.org/10.1144/1354-07930 3-588
Torres-Verdin C, Chunduru RK, Mezzatesta AG (2000) Integrated interpretation of 3D seismic and wireline data to delineate thin oilproducing sands in San Jorge Basin, Argentina. SPE Annual Technical Conference and Exhibition. https://doi.org/10.2118/62910 -ms.

Urosevic M, Bhat G, Grochau MH (2012) Targeting nickel sulfide deposits from 3D seismicreflection data at Kambalda, Australia. Geophysics 77:123-132. https://doi.org/10.1190/geo2011-0514.1

White DJ, Secord D, Malinowski M (2012) 3D seismic imaging of volcanogenic massive sulfide deposits in the Flin Flon mining camp, Canada: Part 1-Seismic results. Geophysics 77:47-58. https://doi.org/10.1190/geo2011-0487.1

Wu QB, Li ZW (2015) Some topics about the identification of channel sand in the exploration of sandstone-type uranium deposits by seismic detect technics. The academic 1:198-203

Wu QB, Liu WS, Li ZW et al (2015) The test of seismic technology for locating the paleo-valley: uranium. Geology 31:193-198. https:// doi.org/10.3969/j.issn.1000-0658.2015.S1.007

Wu QB, Li ZW, Pan ZQ et al (2017) Study on Some Problems in the Seismic Exploration of Sandstone Type Uranium Deposits. Progress in Geophysics 32:2097-2106. https://doi.org/10.6038/ pg20170500

Yang YH, Wang ZL, Xu T et al (2018) A high-efficiency ray-tracing method for 3-d TTI media. Chin J Geophyd 61:1421-433.https:// doi.org/10.6038/cjg2018K0606.

Yuan Y, Gao Y, Bai L, Liu Z (2010) Prestack Kirchhoff time migration of 3D coal seismic data from mining zones. Geophys Prospect 59:455-463. https://doi.org/10.1111/j.1365-2478.2010.00932.x

Zhang JD, Xu GZ, Lin JR (2010) The implication of six kinds of new sandstone-type uranium deposits touranium resources potential in North China. Geol China 37:1434-1450. https://doi.org/10.3969/j. issn.1000-3657.2010.05.020

Zhao XG, Zhang YY, Zhao CP et al (2010) Application review and proposition of geophysical and geochemical exploration in sandstone-type uranium deposit. World Nuclear Geosci 27:31-36. https://doi.org/10.3969/j.issn.1672-0636.2010.01.006

Zhou JJ, Li SX, Jia YQ (2007) The research on the acquistion technolgy of 3-D seismic exploaration in coal field in complicated mountainous area. Seismol Geol 29: 105-113. https://doi.org/10.3969/j. issn.0253-4967.2007.01.009.

Publisher's Note Springer Nature remains neutral with regard to jurisdictional claims in published maps and institutional affiliations. 